\title{
Implementing an online tool for genome- wide validation of survival-associated biomarkers in ovarian-cancer using microarray data from 1287 patients
}

\author{
Balázs Györffy ${ }^{1,2}$, András Lánczky ${ }^{3}$ and Zoltán Szállási ${ }^{4,5}$

\footnotetext{
${ }^{1}$ Research Laboratory of Pediatrics and Nephrology, Hungarian Academy of Sciences, Budapest, Hungary

${ }^{2}$ Laboratory of Functional Genomics, Institute of Pathology, Charité, Berlin, Germany

${ }^{3}$ 2nd Department of Pathology, Semmelweis University Budapest, Budapest, Hungary

${ }^{4}$ Center for Biological Sequence Analysis, Technical University of Denmark, Lyngby, Denmark

${ }^{5}$ Children's Hospital, Harvard Medical School, Boston, Massachusetts, USA
}

(Correspondence should be addressed to B Győrffy who is now at First Department of Pediatrics, Semmelweis University, Bókay János u. 53-54, H-1083 Budapest, Hungary; Email: gyorffy @ kmplot.com)

\begin{abstract}
The validation of prognostic biomarkers in large independent patient cohorts is a major bottleneck in ovarian cancer research. We implemented an online tool to assess the prognostic value of the expression levels of all microarray-quantified genes in ovarian cancer patients. First, a database was set up using gene expression data and survival information of 1287 ovarian cancer patients downloaded from Gene Expression Omnibus and The Cancer Genome Atlas (Affymetrix HG-U133A, HG-U133A 2.0, and HG-U133 Plus 2.0 microarrays). After quality control and normalization, only probes present on all three Affymetrix platforms were retained $(n=22277)$. To analyze the prognostic value of the selected gene, we divided the patients into two groups according to various quantile expressions of the gene. These groups were then compared using progression-free survival $(n=1090)$ or overall survival $(n=1287)$. A Kaplan-Meier survival plot was generated and significance was computed. The tool can be accessed online at www.kmplot. com/ovar. We used this integrative data analysis tool to validate the prognostic power of 37 biomarkers identified in the literature. Of these, CA125 (MUC16; $P=3.7 \times 10^{-5}$, hazard ratio $(\mathrm{HR})=1.4), C D K N 1 B\left(P=5.4 \times 10^{-5}, \mathrm{HR}=1.4\right), K L K 6(P=0.002, \mathrm{HR}=0.79)$, IFNG $(P=0.004$, $\mathrm{HR}=0.81), P 16(P=0.02, \mathrm{HR}=0.66)$, and $B I R C 5(P=0.00017, \mathrm{HR}=0.75)$ were associated with survival. The combination of several probe sets can further increase prediction efficiency. In summary, we developed a global online biomarker validation platform that mines all available microarray data to assess the prognostic power of 22277 genes in 1287 ovarian cancer patients. We specifically used this tool to evaluate the effect of 37 previously published biomarkers on ovarian cancer prognosis.
\end{abstract}

Endocrine-Related Cancer (2012) 19 197-208

\section{Introduction}

With a mortality of 8.4 per 100000 women, ovarian cancer is the most common cause of death among gynecological malignancies (http://seer.cancer.gov) with a 5-year survival rate of $10-30 \%$. Relative to breast cancer, the molecular characteristics of epithelial ovarian cancer(EOC) are more heterogeneous. Despite extensive research, clinical-pathological factors including tumor stage, residual disease after surgery, histological type, and tumor grade are still the most important features related to patient outcome. To date, only two biomarkers have been approved by the Food and Drug Administration (FDA) for monitoring patients with EOC: CA125 (MUC16; Gadducci et al. 1995, 2004, Cooper et al. 2002, Riedinger et al. 2006) and HE4 (WFDC2; Huhtinen et al. 2009, Moore et al. 2009, 2010).

Several additional genes have been suggested as potential biomarkers for the progression of EOC. Low expression of p21 (Ferrandina et al. 2000, Plisiecka-Halasa et al. 2003, Bali et al. 2004), bax 
(Tai et al. 1998, Skirnisdottir et al. 2001), and hTERT (Brustmann 2005) and high expression of survivin (Sui et al. 2002), VEGFR (Hefler et al. 2006), p53 (Buttitta et al. 1997, Reles et al. 2001), human kallikrein 6 (Diamandis et al. 2003), human kallikrein 10 (Luo et al. 2001), Interleukin 6 (Scambia et al. 1995), p27 (Newcomb et al. 1999, Masciullo et al. 2000, Korkolopoulou et al. 2002, Schmider-Ross et al. 2006), cyclin D1 (Bali et al. 2004, Barbieri et al. 2004), cyclin D3 (Levidou et al. 2007), cyclin E (Sui et al. 2001, Farley et al. 2003, Rosen et al. 2006, Bedrosian et al. 2007), Bcl-xL (Materna et al. 2007), cIAP (Psyrri et al. 2006), and ERBB1 (Skirnisdottir et al. 2004, Psyrri et al. 2005) could represent prognostic variables for poor clinical outcome. In addition, the genome-wide investigation of adequate clinical cohorts delivers unprecedented amount of potential new biomarkers (Denkert et al. 2009).

However, most of these potential biomarkers have neither been validated in multivariate analyses nor was their discriminative power validated in large clinical cohorts. Even more alarmingly, many reports have questioned or rejected a correlation between a proposed biomarker and clinical outcome. Doubts were raised regarding the markers CA125 (Cruickshank et al. 1987, van der Burg et al. 1988, Rustin et al. 1989, Sevelda et al. 1989), cyclin D1 (Masciullo et al. 1997, Dhar et al. 1999), p16 (Milde-Langosch et al. 2003, Khouja et al. 2007), p21 (Baekelandt et al. 1999, Levesque et al. 2000, Schuyer et al. 2001), p27 (Schmider et al. 2000), p53 (Smith-Sorensen et al. 1998, Wang et al. 2004, Green et al. 2006), Bcl-xl (Baekelandt et al. 2000), cIAP (Kleinberg et al. 2007), survivin (Cohen et al. 2003, Ferrandina et al. 2005), hTERT (Wisman et al. 2003, Widschwendter et al. 2004), ERBB1 (Berchuck et al. 1991, Meden et al. 1995, Nielsen et al. 2004), and ERBB2 (Rubin et al. 1993, Meden et al. 1995, Ross et al. 1999, Nielsen et al. 2004, Riener et al. 2004).

Given the large number of potential biomarkers for EOC, the immediate challenge is to validate the most robust candidates eligible for further investigation. Recent advances in genomic technologies together with powerful bioinformatic tools can enable us to deliver this prerequisite. We recently developed an online biomarker validation tool using microarray data of 2000 breast cancer patients (Gyorffy et al. 2010). In this, the expression of a selected gene can be used to split patients into groups, and the proportional survival of these groups is compared to each other.

In this study, our aim was to implement an online survival analysis tool for the rapid assessment of prognosis-related genes in ovarian cancer and to test the validity of previously proposed biomarkers. Furthermore, we also developed additional analysis options including the computation of multigenic prognosis predictors and the option of grouping patients based on applied treatment protocols.

\section{Materials and methods Collection of ovarian cancer microarray data sets}

We searched Gene Expression Omnibus (GEO; http:// www.ncbi.nlm.nih.gov/geo/) and The Cancer Genome Atlas (TCGA; http://cancergenome.nih.gov) to identify data sets suitable for the analysis. In this, the keywords 'ovarian', 'cancer', 'survival', 'gp196', 'gpl570', and 'gp1571' were used. Only publications with available raw microarray gene expression data, clinical survival information, and at least 20 patients were included. Only three microarray platforms, GPL96 (Affymetrix HG-U133A), GPL570 (Affymetrix HG-U133 Plus 2.0), and GPL571/GPL3921 (Affymetrix HG-U133A 2.0), were considered because they are frequently used and because these particular arrays have 22277 probe sets (representing 13435 unique genes) in common. The use of almost identical platforms and identical probe sets is vital because different platforms for gene expression profiling measure expression of the same gene with varying accuracy, on different relative scales, and with diverse dynamic ranges (Tan et al. 2003). Finally, we controlled all samples using the ranked expression of all genes to identify repeatedly published microarrays.

\section{Setup of server for online survival calculation}

The raw.CEL files were MAS5 normalized in the $\mathrm{R}$ statistical environment (www.r-project.org) using the affy Bioconductor library (Gautier et al. 2004). MAS5 can be applied to individual chips, making future extensions of the database uncomplicated. Furthermore, MAS5 ranked among the best normalization methods when compared with the results of RT-PCR measurements in our recent study (Gyorffy et al. 2009). For the analysis, only probes measured on GPL96, GPL570, and GPL571/GPL3921 were retained $(n=22277)$. At this stage, we performed a second scaling normalization to set the average expression on each chip to 1000 . Although this technique cannot remove all, but it can significantly reduce batch effects (Sims et al. 2008). We integrated the gene expression and clinical data using PostgreSQL, an open-source object-relational database system (www.postgresql. org). Data security is ensured through PostgreSQL 
permissions that are imposed on individual tables in the project databases.

The KMplot web application can be reached in a platform-independent user interface. The interactivity of the service is increased by the usage of JavaScript and Ajax technologies. The server is hosted on Debian Linux (www.debian.org) and is powered by Apache (www.apache.org). he server-side scripts were developed in hypertext preprocessor (PHP), which controls the analysis requests and delivers the results. Open Database Connectivity is used as a middleware layer between the $\mathrm{R}$ and the PostgreSQL database via the RODBC package (cran.r-project.org/ package $=\mathrm{RODBC}$ ). The package 'survival' is used to calculate and plot Kaplan-Meier survival curves, and the number-at-risk is indicated below the main plot. Hazard ratio (HR; and 95\% confidence intervals) and logrank $P$ are calculated and displayed. The central server for the Kaplan-Meier plotter for ovarian cancer can be reached at www.kmplot.com/ovar.

\section{Probe set options}

We also implemented a set of probe-set-related options, including the option to use all probe sets available for a given gene on the microarray simultaneously and to use a combined expression of several probe sets. Using this option, it is possible to assess the effect of the mean expression of gene combinations on survival.

In addition, bee swarm plot can be drawn using the beeswarm package (www.cbs.dtu.dk/ eklund/beeswarm/). The bee swarm plot is capable of visualizing gene expression as nonoverlapping points in a one-dimensional scatter plot. A bee swarm plot can be used to quickly identify outlier samples and genes with bimodal distribution.

\section{Validation of previously published EOC biomarkers}

A PubMed search was performed using the keywords 'ovarian cancer', 'survival', 'biomarker', and 'gene expression' to identify genes described in the literature as potential EOC biomarkers. Then, using PubMed gene, we added a unique gene symbol for each of the genes and identified the corresponding Affymetrix probe set IDs. The capability of these genes to predict survival was measured by using the probe set IDs in the online analysis tool.

In the combination of several markers, their mean expression is first computed for each sample. Then, the median of these is used for splitting the patients into cohorts during the analysis.

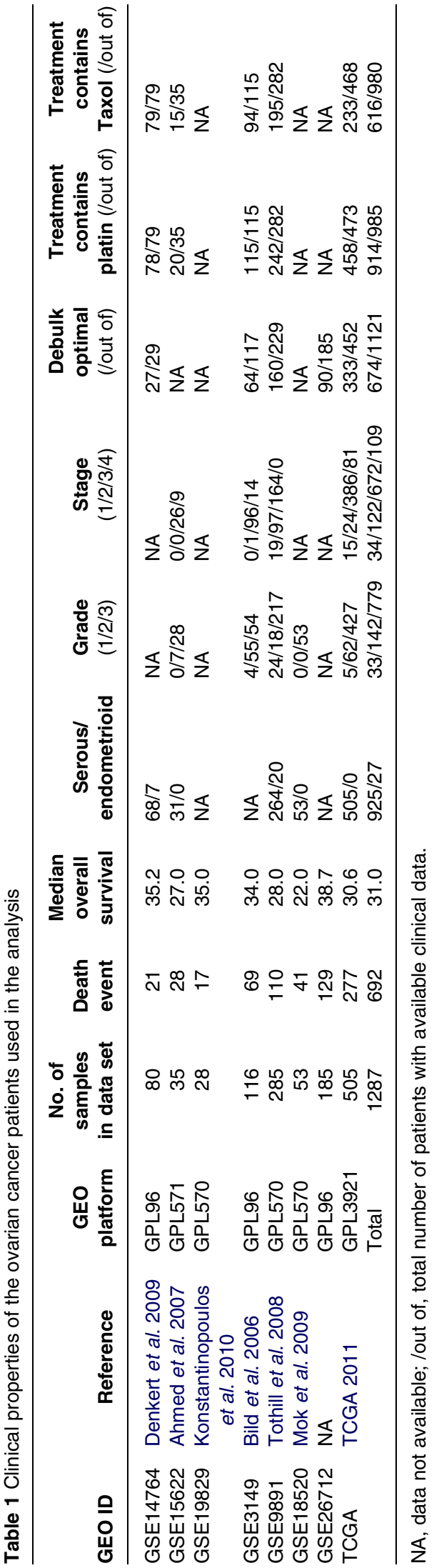


Table 2 The association between prognostic markers and progression-free survival. The patients were divided into two groups as having higher or lower expression as compared to the median. The markers were analyzed in subsets of patients with equivalent clinical characteristics to the cohorts in which the association has previously been described

\begin{tabular}{|c|c|c|c|c|c|c|c|c|}
\hline Symbol & Gene & Reference & Survival & $\begin{array}{l}\text { Analyzed in } \\
\text { the cohort of }\end{array}$ & $\begin{array}{l}\text { Affymetrix } \\
\text { ID }\end{array}$ & $\mathbf{Q}$ & HR & $\boldsymbol{P}$ \\
\hline$C A(M \cup C 16) 125$ & CA 125 & $\begin{array}{l}\text { Gadducci et al. 1995, } \\
\text { Cooper et al. 2002, } \\
\text { Gadducci et al. 2004, } \\
\text { Riedinger et al. 2006 }\end{array}$ & PFS & All patients & $\begin{array}{l}\text { 220196_at } \\
\text { 201384_s_at } \\
\text { 201383_s_at }\end{array}$ & $\begin{array}{l}2 \\
1 \\
1\end{array}$ & $\begin{array}{l}\text { NS } \\
1.3 \\
1.4\end{array}$ & $\begin{array}{l}\text { NS } \\
0.0003^{\star} \\
3.7 \times 10^{-5 *, a}\end{array}$ \\
\hline KRT19 & Cytokeratin 19 & $\begin{array}{l}\text { Tempfer et al. 1998, } \\
\text { Gadducci et al. } 2001\end{array}$ & PFS & Debulk= subopt. & 201650_at & 1 & NS & NS \\
\hline$K L K 6$ & Kallikrein 6 & Diamandis et al. 2003 & PFS & All patients & $\begin{array}{l}\text { 216699_s_at } \\
\text { 204733_at }\end{array}$ & $\begin{array}{l}2 \\
1\end{array}$ & $\begin{array}{l}0.79 \\
\text { NS }\end{array}$ & $\begin{array}{l}\mathbf{0 . 0 0 2}^{*} \\
\text { NS }\end{array}$ \\
\hline$K L K 10$ & Kallikrein 10 & Luo et al. 2001 & PFS & Stage $=3+4$ & $\begin{array}{l}\text { 209792_s_at } \\
\text { 215808_at }\end{array}$ & $\begin{array}{l}1 \\
3\end{array}$ & $\begin{array}{l}\text { NS } \\
\text { NS }\end{array}$ & $\begin{array}{l}\text { NS } \\
\text { NS }\end{array}$ \\
\hline IL6 & Interleukin 6 & Scambia et al. 1995 & os & All patients & 205207_at & 2 & NS & NS \\
\hline IL7 & Interleukin 7 & Lambeck et al. 2007 & OS & All patients & 206693_at & 3 & NS & NS \\
\hline IFNG & $\gamma$-Interferon & Marth et al. 2004 & PFS & All patients & 210354_at & 3 & 0.81 & $0.004^{\star}$ \\
\hline FAS & sFas & $\begin{array}{l}\text { Hefler et al. } 2000 \\
\text { Konno et al. } 2000\end{array}$ & PFS & All patients & $\begin{array}{l}\text { 204780_s_at } \\
204781 \text { s_at } \\
212218 \text { s_at } \\
215719 \text { _at } \\
216252 \text { x_at } \\
217006 \text { x at }\end{array}$ & $\begin{array}{l}1 \\
1 \\
1 \\
2 \\
2 \\
3\end{array}$ & $\begin{array}{l}1.2 \\
\text { NS } \\
0.84 \\
\text { NS } \\
\text { NS } \\
\text { NS }\end{array}$ & $\begin{array}{l}0.017 \\
\text { NS } \\
0.024 \\
\text { NS } \\
\text { NS } \\
\text { NS }\end{array}$ \\
\hline VEGFR & VEGFR & Hefler et al. 2006 & os & All patients & 203934_at & 2 & 1.2 & 0.064 \\
\hline CCND1 & Cyclin D1 & $\begin{array}{l}\text { Bali et al. } 2004 \text {, Barbieri } \\
\text { et al. } 2004\end{array}$ & OS & Stage $=3+4$ & $\begin{array}{l}\text { 208711_s_at } \\
\text { 208712_at }\end{array}$ & $\begin{array}{l}1 \\
1\end{array}$ & $\begin{array}{l}\text { NS } \\
\text { NS }\end{array}$ & $\begin{array}{l}\text { NS } \\
\text { NS }\end{array}$ \\
\hline CCND3 & Cyclin D3 & Levidou et al. 2007 & os & All patients & 201700_at & 1 & NS & NS \\
\hline CCNE & Cyclin E & $\begin{array}{l}\text { Sui et al. 2001, Farley } \\
\text { et al. 2003, Rosen } \\
\text { et al. 2006, Bedrosian } \\
\text { et al. } 2007\end{array}$ & os & Debulk= subopt. & $\begin{array}{l}\text { 213523_at } \\
\text { 205034_at } \\
\text { 211814_s_at }\end{array}$ & $\begin{array}{l}2 \\
2 \\
3\end{array}$ & $\begin{array}{l}\text { NS } \\
\text { NS } \\
\text { NS }\end{array}$ & $\begin{array}{l}\text { NS } \\
\text { NS } \\
\text { NS }\end{array}$ \\
\hline$P(C D K N 2 B) 15$ & $\mathrm{p} 15$ & Kudoh et al. 2002 & PFS & All patients & $\begin{array}{l}\text { 204599_s_at } \\
212857 \text { x_at } \\
214512 \text { _sat } \\
221727 \text { at } \\
218708 \text { at }\end{array}$ & $\begin{array}{l}1 \\
1 \\
1 \\
3 \\
1\end{array}$ & $\begin{array}{l}\text { NS } \\
1.3 \\
1.2 \\
\text { NS } \\
\text { NS }\end{array}$ & $\begin{array}{l}\text { NS } \\
\mathbf{0 . 0 0 0 5 ^ { \star }} \\
0.01 \\
\text { NS } \\
\text { NS }\end{array}$ \\
\hline$P(C D K N 2 A) 16$ & $\mathrm{p} 16$ & $\begin{array}{l}\text { Katsaros et al. } 2004 \\
\text { Kommoss et al. } 2007\end{array}$ & PFS & Debulk= subopt. & $\begin{array}{l}\text { 207039_at } \\
\text { 209644_x_at } \\
\text { 211156_at }\end{array}$ & $\begin{array}{l}2 \\
1 \\
3\end{array}$ & $\begin{array}{l}\mathbf{0 . 6 6} \\
\text { NS } \\
0.69\end{array}$ & $\begin{array}{l}\mathbf{0 . 0 0 2}^{\star} \\
\text { NS } \\
0.009\end{array}$ \\
\hline CDKN1A & p21 & $\begin{array}{l}\text { Ferrandina et al. } 2000 \\
\text { Plisiecka-Halasa et al. } \\
\text { 2003, Bali et al. } 2004\end{array}$ & PFS & $\begin{array}{l}\text { Histology }= \\
\text { serous }\end{array}$ & 202284_s_at & 1 & NS & NS \\
\hline CDKN1B & p27 & $\begin{array}{l}\text { Newcomb et al. } 1999 \text {, } \\
\text { Masciullo et al. } 2000 \text {, } \\
\text { Korkolopoulou et al. } \\
\text { 2002, Schmider-Ross } \\
\text { et al. } 2006\end{array}$ & PFS & All patients & 209112_at & 1 & 1.4 & $5.4 \times 10^{-5 \star, a}$ \\
\hline$R B 1$ & $\mathrm{pRB}$ & $\begin{array}{l}\text { Dong et al. 1997, } \\
\text { Konstantinidou et al. } \\
2003\end{array}$ & os & Stage $=1$ & $\begin{array}{l}\text { 203132_at } \\
211540 \text { _s_at }\end{array}$ & $\begin{array}{l}1 \\
3\end{array}$ & $\begin{array}{l}\text { NS } \\
\text { NS }\end{array}$ & $\begin{array}{l}\text { NS } \\
\text { NS }\end{array}$ \\
\hline$E 2 F 1$ & $\mathrm{E} 2 \mathrm{~F} 1$ & Suh et al. 2008 & PFS & All patients & 2028_s_at & $\begin{array}{l}1 \\
3\end{array}$ & $\begin{array}{l}0.83 \\
\text { NS }\end{array}$ & $\begin{array}{l}0.017 \\
\text { NS }\end{array}$ \\
\hline E2F2 & E2F2 & Reimer et al. 2007 & PFS & All patients & 207042_at & 3 & 0.86 & 0.037 \\
\hline E2F4 & E2F4 & Reimer et al. 2007 & PFS & All patients & $\begin{array}{l}\text { 202248_at } \\
\text { 38707_r_at }\end{array}$ & $\begin{array}{l}3 \\
1\end{array}$ & $\begin{array}{l}0.85 \\
\text { NS }\end{array}$ & $\begin{array}{l}0.034 \\
\text { NS }\end{array}$ \\
\hline TP53 & p53 & $\begin{array}{l}\text { Buttitta et al. 1997, Reles } \\
\text { et al. } 2001\end{array}$ & PFS & Stage $=3+4$ & $\begin{array}{l}\text { 211300_s_at } \\
\text { 201746_at }\end{array}$ & $\begin{array}{l}2 \\
1\end{array}$ & $\begin{array}{l}\text { NS } \\
0.84\end{array}$ & $\begin{array}{l}\text { NS } \\
0.075\end{array}$ \\
\hline TP73 & p73 & Becker et al. 2006 & os & All patients & 220804_s_at & 3 & NS & NS \\
\hline$B A X$ & bax & $\begin{array}{l}\text { Tai et al. 1998, } \\
\quad \text { Skirnisdottir et al. } 2001\end{array}$ & PFS & $\begin{array}{l}\text { Therapy }= \\
\text { contains Taxol }\end{array}$ & $\begin{array}{l}\text { 208478_s_at } \\
211833 \text { _s_at }\end{array}$ & $\begin{array}{l}2 \\
2\end{array}$ & $\begin{array}{l}\text { NS } \\
\text { NS }\end{array}$ & $\begin{array}{l}\text { NS } \\
\text { NS }\end{array}$ \\
\hline
\end{tabular}


Table 2 continued

\begin{tabular}{|c|c|c|c|c|c|c|c|c|}
\hline Symbol & Gene & Reference & Survival & $\begin{array}{l}\text { Analyzed in } \\
\text { the cohort of }\end{array}$ & $\begin{array}{l}\text { Affymetrix } \\
\text { ID }\end{array}$ & $\mathbf{Q}$ & HR & $\boldsymbol{P}$ \\
\hline \multirow[t]{3}{*}{ BCL2L1 } & \multirow[t]{3}{*}{$\mathrm{Bcl}-\mathrm{xl}$} & \multirow[t]{3}{*}{ Materna et al. 2007} & \multirow[t]{3}{*}{ PFS } & \multirow[t]{3}{*}{ All patients } & 212312_at & 1 & 0.86 & 0.04 \\
\hline & & & & & 215037_s_at & 2 & NS & NS \\
\hline & & & & & 206665_s_at & 3 & NS & NS \\
\hline BIRC2 & clAP & Psyrri et al. 2006 & os & Stage $=3+4$ & 202076_at & 1 & NS & NS \\
\hline \multirow[t]{3}{*}{ BIRC5 } & \multirow[t]{3}{*}{ Survivin } & \multirow[t]{3}{*}{ Sui et al. 2002} & \multirow[t]{3}{*}{ PFS } & \multirow[t]{3}{*}{ All patients } & 210334_x_at & 2 & 0.75 & $0.00017^{*}$ \\
\hline & & & & & 202094_at & 2 & 0.84 & 0.018 \\
\hline & & & & & 202095_s_at & 1 & 0.84 & 0.018 \\
\hline TERT & hTERT & Brustmann 2005 & os & $\begin{array}{c}\text { Histology }= \\
\text { serous }\end{array}$ & 207199_at & 3 & NS & NS \\
\hline \multirow[t]{6}{*}{ EGFR } & \multirow[t]{6}{*}{ ERBB1 } & \multirow{6}{*}{$\begin{array}{l}\text { Skirnisdottir et al. } 2004 \text {, } \\
\text { Psyrri et al. } 2005\end{array}$} & \multirow[t]{6}{*}{ PFS } & \multirow[t]{6}{*}{ Stage $=1+2$} & 201983_s_at & 1 & NS & NS \\
\hline & & & & & 201984_s_at & 1 & NS & NS \\
\hline & & & & & 211551_at & 2 & NS & NS \\
\hline & & & & & 210984_x_at & 3 & NS & NS \\
\hline & & & & & 211550_at & 3 & NS & NS \\
\hline & & & & & 211607_x_at & 3 & NS & NS \\
\hline \multirow[t]{2}{*}{ ERBB2 } & \multirow[t]{2}{*}{ ERBB2 } & \multirow[t]{2}{*}{ Lassus et al. 2004} & \multirow[t]{2}{*}{ PFS } & \multirow{2}{*}{$\begin{array}{c}\text { Histology }= \\
\text { serous }\end{array}$} & 210930_s_at & 3 & NS & NS \\
\hline & & & & & 216836_s_at & 1 & NS & NS \\
\hline \multirow[t]{5}{*}{ MET } & \multirow[t]{5}{*}{ c-Met } & \multirow{5}{*}{ Sawada et al. 2007} & \multirow[t]{5}{*}{ os } & \multirow[t]{5}{*}{ Stage $=3+4$} & 217828_at & 1 & NS & NS \\
\hline & & & & & 203510_at & 1 & NS & NS \\
\hline & & & & & 211599_x_at & 1 & NS & NS \\
\hline & & & & & 213807_x_at & 2 & NS & NS \\
\hline & & & & & 213816_s_at & 3 & NS & NS \\
\hline MMP2 & MMP-2 & Torng et al. 2004 & PFS & $\begin{array}{c}\text { Histology }= \\
\text { endom. }\end{array}$ & 201069_at & 1 & 0.33 & 0.05 \\
\hline MMPg & MMP-9 & Sillanpaa et al. 2007 & os & Stage $=1$ & 203936_s_at & 1 & NS & NS \\
\hline \multirow[t]{4}{*}{ MMP14 } & \multirow[t]{4}{*}{ MT1-MMP } & \multirow[t]{4}{*}{ Kamat et al. 2006} & os & Stage $=2+3+4$ & 160020_at & 1 & NS & NS \\
\hline & & & & & 202828_s_at & 1 & NS & NS \\
\hline & & & & & 202827_s_at & 2 & NS & NS \\
\hline & & & & & 217279_x_at & 3 & NS & NS \\
\hline WFDC2 (HE4) & $\begin{array}{r}\text { Epididymis } \\
\text { protein } 4\end{array}$ & $\begin{array}{l}\text { Huhtinen et al. 2009, } \\
\text { Moore et al. 2009, } \\
2010\end{array}$ & PFS & All patients & 203892_at & 1 & NS & NS \\
\hline SERPINB5 & Maspin & Secord et al. 2006 & PFS & Debulk= subopt. & 204855_at & 1 & NS & NS \\
\hline$B R C A 1$ & BRCA1 & Thrall et al. 2006 & os & All patients & 211851_x_at & 3 & 0.82 & 0.01 \\
\hline & & & & & 204531_s_at & 2 & NS & NS \\
\hline$E R C C 1$ & ERCC1 & Darcy \& Tian 2007 & PFS & Stage $=3$ & 203719_at & 1 & NS & NS \\
\hline & & & & $\begin{array}{l}\text { Therapy }= \\
\text { Tax+Plat }\end{array}$ & 203720_s_at & 1 & NS & NS \\
\hline
\end{tabular}

PFS, progression-free survival; OS, overall survival, HR, hazard ratio; Q, quality score for the probe set as measured after normalization across the entire data set (1, average expression over 500 or maximal expression over 1000; 2 , intermediate probes; 3 , average expression below 100); NS, not significant (significance over 0.05 ). *bold indicates $\mathrm{P}<0.005$.

a See Kaplan-Meier plots in Fig. 1.

\section{Results}

\section{Construction of combined ovarian cancer microarray database}

We identified 1287 unique patients in eight data sets meeting our criteria in GEO and TCGA. In the GSE3149 data set, we found two samples repeatedly published $(\mathrm{GSM} 70546=\mathrm{GSM} 70547$ and $\mathrm{GSM} 70511=\mathrm{GSM}$ 70512). As for these samples the unique recognition of the appropriate clinical information was not possible, we removed them from the final database. Of the above, $72 \%$ have serous and $2 \%$ have endometrioid tumors. Patients are distributed across stage $1(n=34,3.6 \%)$, stage $2(n=122,13 \%)$, stage $3(n=672,71.7 \%)$, and stage $4(n=109,11.6 \%)$. Debulking was optimal (residual tumor $<1 \mathrm{~cm}$ ) in 674 out of 1119 patients. The median overall survival is 31.0 months, 1090 patients have progression-free survival data, and 1287 have overall survival data. (note: some publications report 'disease-free survival' (Konstantinopoulos et al. 2010) or 'relapse-free survival' (Tothill et al. 2008) instead of 'progression-free survival'. These were merged as 'progression-free survival' to enable a meta-analysis of the complete database.). A summary of the clinical characteristics of the patients in each data set used in the analysis is shown in Table 1. 


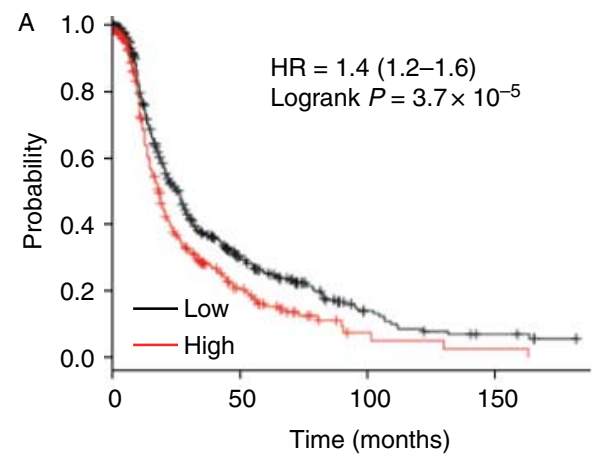

B

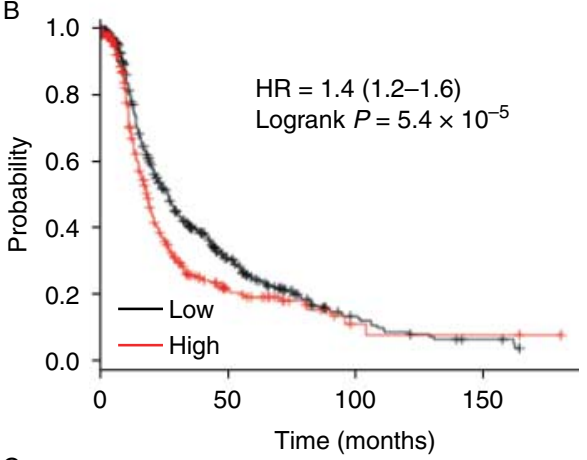

C
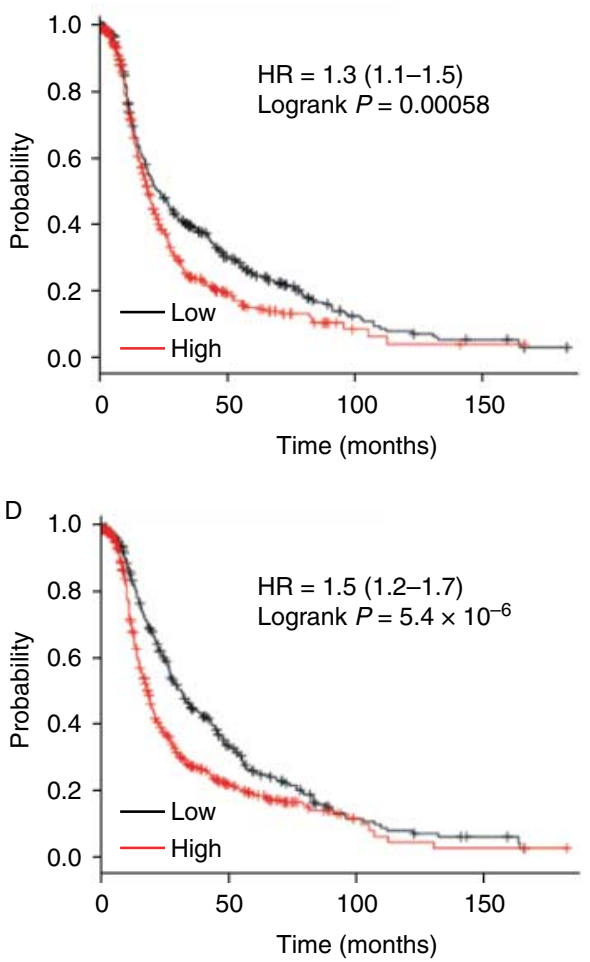

Figure 1 Survival plots depicting the good prognostic effect on progression-free survival of the lower expression of CA125 (A, 201383_s_at), CDKN1B (B, 209112_at), and P15 (C, 212857_x_at). Classification using the mean expression of two genes $(C A 125+C D K N 1 B)$ with a cutoff at the lower quartile results in increased discriminative power (D).

\section{Setup of online survival analysis platform}

The Kaplan-Meier plot shows the association between the investigated marker and survival in which the samples are grouped according to the median (or upper or lower quartile) expression of the selected gene. Before running the analysis, the patients can be filtered using stage, histology, grade, and treatment parameters including debulking status and applied chemotherapy. In addition, as an alternative to progression-free survival, overall survival can also be investigated.

Since there is an already established biomarker (CA125), a clinician might be interested in a specific clinical cohort of patients having low CA125 levels. Therefore, we added an additional filtering option in which only patients having an average CA125 expression (average of the two reliable probe sets) below the lower quartile of all patients are included. We must note that while this study measured tissue levels of CA125, the FDA-approved test for ovarian cancer is serum based.

\section{Validation of previously published EOC biomarkers}

Markers of ovarian cancer prognosis have been identified using literature search. We computed Kaplan-Meier plots for 37 proposed biomarkers to assess their effect on prognosis (for the complete results see Table 2 and Fig. 1). All biomarkers were investigated in the same cohort in which they were discovered. High significance was achieved for $C A 125$, KLK6, IFNG, P15, P16, CDKN1B, and BIRC5. In addition, we have also run the analysis for predicting progression-free survival in all patients.

In an effort to improve accuracy, a pair-wise combination of the three best performing probe sets was assessed independently. The combination of $C A 125$ and $C D K N 1 B$ with a cutoff at the lower quartile resulted in classification significance superior to the power of the markers independently ( $\mathrm{HR}=1.5$ and $P=5.4 \times 10^{-6}$ vs $\mathrm{HR}=1.4, P=3.7 \times 10^{-5}$ and $\mathrm{HR}=1.4, P=5.4 \times 10^{-5}$ for $C A 125$ and $C D K N 1 B$, respectively, see Table 2 and Fig. 1).

\section{Discussion}

The validation of prognostic biomarkers is a major bottleneck in ovarian cancer research. Here, we combined multiple large microarray data sets to increase the statistical power for a meta-analysis of 22277 genes. We developed a freely accessible online tool to estimate the prognostic value of any selected gene in a large cohort of clinical patients. After dividing 
the patients into two groups based on the expression of the selected gene, a Kaplan-Meier plot is generated. The implemented computations are performed in real time on our server. This enables seamless future extension using new data sets or new filtering options.

We have integrated data sets from GEO and TCGA $\sim 40 \%$ of samples used by www.kmplot.com/ovar are from the TCGA repository. For the TCGA samples alone, there is an option to perform analyses in the caIntegrator website (https://caintegrator.nci.nih.gov). The samples in TCGA are open access or restricted (access is granted to NIH staff and to eRA Commons principal investigators) - however, the Affymetrix HG-U133 microarray profiles for the ovarian cancer patients are publicly available. We plan to continuously incorporate new GEO data sets as well as new TCGA samples in www.kmplot.com.

In contrast to breast cancer, where several already approved markers are in clinical use, in ovarian cancer only minimal progress has been made in recent years. When investigating the previously proposed biomarkers, we found that only few genes are actually capable of predicting outcome in our combined data set: CA125, P15, KLK6, IFNG, P16, CDKN1B, and $B I R C 5$. Of these, $C A 125$ and $C D K N 1 B$ resulted in very robust significance. These results may reflect the high genetic heterogeneity of ovarian cancer (Gyorffy et al. 2008) and emphasize the importance of potential improvements in prognosis.

The most extensively studied marker for EOC is CA125 (Gadducci et al. 1995, 2004, Cooper et al. 2002, Riedinger et al. 2006), and determining its concentration in serum is essential for monitoring ovarian cancer progression. Fifty percent increase in serum $C A 125$ level has been correlated to progression, and present progression definition of the Gynecological Cancer Intergroup defines progression based on two elevated serum $C A 125$ levels. According to our results, tumor level of $C A 125$ gene was able to predict later clinical outcome. Notably, we observed two different probe sets representing CA125 as significant. A third probe set did not show significant prognostic power, but it has also displayed low quality in terms of average expression as compared to the probe sets with significant prognostic power.

The role of the cell cycle control gene p27 (CDKN1B) as a prognostic marker in ovarian cancer was suggested in several studies (Newcomb et al. 1999, Masciullo et al. 2000, Korkolopoulou et al. 2002, Schmider-Ross et al. 2006). In addition, numerous recent analyses also confirmed its role in 205 (Lee et al. 2011), 131 (Skirnisdottir et al. 2011), and 339 (Duncan et al. 2010) patients. p27 is measured by only one probe set on the microarrays, and this probe set delivered high prognostic power in our analysis.

$P 15$ is a tumor suppressor gene previously associated with ovarian cancer progression in 45 patients (Kudoh et al. 2002). The methylation status of $P 15$ has also been investigated but was not an independent prognostic factor in 145 patients (Tam et al. 2007). One of the probe sets measuring P15 (212857_x_at) delivered a high prognostic potential.

To this point, we have investigated the prognostic power of individual probe sets. However, recent reports based on genomic technologies use not only single selected genes, but also a combination of these. In addition, some of the markers are not related to ovarian cancer prognosis in general, but have discriminative potential in one of the subgroups, or are related to different treatment regimens. While the evaluation of all potential markers and all eligible combinations is beyond the scope of this study, our online tool was set up exactly to enable researchers to perform these tests on our database.

In summary, we reviewed previously reported biomarkers of ovarian cancer prognosis and assessed their performance in a meta-analysis of 1297 ovarian cancer patients. We also developed an online biomarker validation platform to mine all available microarray data to assess the prognostic power of 22277 genes.

\section{Declaration of interest}

The authors declare that there is no conflict of interest that could be perceived as prejudicing the impartiality of the research reported.

\section{Funding}

B Győrffy study was supported by the OTKA PD 83154, by the TAMOP-4.2.1.B-09/1/KMR-2010-0001, by the ETT 029/2009 grant and by the Alexander von Humboldt Stiftung. Z Szállási was supported by the Breast Cancer Research Foundation.

\section{References}

Ahmed AA, Mills AD, Ibrahim AE, Temple J, Blenkiron C, Vias M, Massie CE, Iyer NG, McGeoch A, Crawford R et al. 2007 The extracellular matrix protein TGFBI induces microtubule stabilization and sensitizes ovarian cancers to paclitaxel. Cancer Cell 12 514-527. (doi:10. 1016/j.ccr.2007.11.014)

Baekelandt M, Holm R, Trope CG, Nesland JM \& Kristensen GB 1999 Lack of independent prognostic significance of p21 and p27 expression in advanced ovarian cancer: an immunohistochemical study. Clinical Cancer Research 5 2848-2853. 
Baekelandt M, Holm R, Nesland JM, Trope CG \& Kristensen GB 2000 Expression of apoptosis-related proteins is an independent determinant of patient prognosis in advanced ovarian cancer. Journal of Clinical Oncology 18 3775-3781.

Bali A, O'Brien PM, Edwards LS, Sutherland RL, Hacker NF \& Henshall SM 2004 Cyclin D1, p53, and p21Waf1/Cip1 expression is predictive of poor clinical outcome in serous epithelial ovarian cancer. Clinical Cancer Research 10 5168-5177. (doi:10.1158/10780432.CCR-03-0751)

Barbieri F, Lorenzi P, Ragni N, Schettini G, Bruzzo C, Pedulla F \& Alama A 2004 Overexpression of cyclin D1 is associated with poor survival in epithelial ovarian cancer. Oncology 66 310-315. (doi:10.1159/000078332)

Becker K, Pancoska P, Concin N, Vanden Heuvel K, Slade N, Fischer M, Chalas E \& Moll UM 2006 Patterns of p73 $\mathrm{N}$-terminal isoform expression and p53 status have prognostic value in gynecological cancers. International Journal of Oncology 29 889-902.

Bedrosian I, Lee C, Tucker SL, Palla SL, Lu K \& Keyomarsi K 2007 Cyclin E-associated kinase activity predicts response to platinum-based chemotherapy. Clinical Cancer Research 13 4800-4806. (doi:10.1158/10780432.CCR-07-0142)

Berchuck A, Rodriguez GC, Kamel A, Dodge RK, Soper JT, Clarke-Pearson DL \& Bast RC Jr 1991 Epidermal growth factor receptor expression in normal ovarian epithelium and ovarian cancer. I. Correlation of receptor expression with prognostic factors in patients with ovarian cancer. American Journal of Obstetrics and Gynecology 164 669-674.

Bild AH, Yao G, Chang JT, Wang Q, Potti A, Chasse D, Joshi MB, Harpole D, Lancaster JM, Berchuck A et al. 2006 Oncogenic pathway signatures in human cancers as a guide to targeted therapies. Nature 439 353-357. (doi:10.1038/nature04296)

Brustmann H 2005 Immunohistochemical detection of human telomerase reverse transcriptase (hTERT) and c-kit in serous ovarian carcinoma: a clinicopathologic study. Gynecological Oncology 98 396-402. (doi:10.1016/j.ygyno.2005.04.035)

van der Burg ME, Lammes FB, van Putten WL \& Stoter G 1988 Ovarian cancer: the prognostic value of the serum half-life of CA125 during induction chemotherapy. Gynecological Oncology 30 307-312. (doi:10.1016/00908258(88)90244-2)

Buttitta F, Marchetti A, Gadducci A, Pellegrini S, Morganti M, Carnicelli V, Cosio S, Gagetti O, Genazzani AR \& Bevilacqua G 1997 p53 alterations are predictive of chemoresistance and aggressiveness in ovarian carcinomas: a molecular and immunohistochemical study. British Journal of Cancer 75 230-235. (doi:10.1038/bjc. 1997.38)

Cohen C, Lohmann CM, Cotsonis G, Lawson D \& Santoianni R 2003 Survivin expression in ovarian carcinoma: correlation with apoptotic markers and prognosis. Modern Pathology 16 574-583. (doi:10.1097/01.MP.0000073868. 31297.B0)

Cooper BC, Sood AK, Davis CS, Ritchie JM, Sorosky JI, Anderson B \& Buller RE 2002 Preoperative CA125 levels: an independent prognostic factor for epithelial ovarian cancer. Obstetrics and Gynecology 100 59-64. (doi:10.1016/S0029-7844(02)02057-4)

Cruickshank DJ, Fullerton WT \& Klopper A 1987 The clinical significance of pre-operative serum CA 125 in ovarian cancer. British Journal of Obstetrics and Gynaecology 94 692-695. (doi:10.1111/j.1471-0528. 1987.tb03177.x)

Darcy KM, Tian C \& Reed E 2007 A Gynecologic Oncology Group study of platinum-DNA adducts and excision repair cross-complementation group 1 expression in optimal, stage III epithelial ovarian cancer treated with platinum-taxane chemotherapy. Cancer Research 67 4474-4481. (doi:10.1158/0008-5472.CAN-06-4076)

Denkert C, Budczies J, Darb-Esfahani S, Gyorffy B, Sehouli J, Konsgen D, Zeillinger R, Weichert W, Noske A, Buckendahl AC et al. 2009 A prognostic gene expression index in ovarian cancer - validation across different independent data sets. Journal of Pathology 218 273-280. (doi:10.1002/path.2547)

Dhar KK, Branigan K, Parkes J, Howells RE, Hand P, Musgrove C, Strange RC, Fryer AA, Redman CW \& Hoban PR 1999 Expression and subcellular localization of cyclin D1 protein in epithelial ovarian tumour cells. British Journal of Cancer 81 1174-1181. (doi:10.1038/sj. bjc.6690826)

Diamandis EP, Scorilas A, Fracchioli S, Van Gramberen M, De Bruijn H, Henrik A, Soosaipillai A, Grass L, Yousef GM, Stenman UH et al. 2003 Human kallikrein 6 (hK6): a new potential serum biomarker for diagnosis and prognosis of ovarian carcinoma. Journal of Clinical Oncology 21 1035-1043. (doi:10.1200/JCO.2003.02.022)

Dong Y, Walsh MD, McGuckin MA, Cummings MC, Gabrielli BG, Wright GR, Hurst T, Khoo SK \& Parsons PG 1997 Reduced expression of retinoblastoma gene product $(\mathrm{pRB})$ and high expression of $\mathrm{p} 53$ are associated with poor prognosis in ovarian cancer. International Journal of Cancer 74 407-415. (doi:10.1002/(SICI)1097-0215(19970822)74:4<407:: AID-IJC8 > 3.0.CO;2-Z)

Duncan TJ, Al-Attar A, Rolland P, Harper S, Spendlove I \& Durrant LG 2010 Cytoplasmic p27 expression is an independent prognostic factor in ovarian cancer. International Journal of Gynecological Pathology 29 8-18. (doi:10.1097/PGP.0b013e3181b64ec3)

Farley J, Smith LM, Darcy KM, Sobel E, O'Connor D, Henderson B, Morrison LE \& Birrer MJ 2003 Cyclin E expression is a significant predictor of survival in advanced, suboptimally debulked ovarian epithelial cancers: a Gynecologic Oncology Group study. Cancer Research 63 1235-1241. 
Ferrandina G, Stoler A, Fagotti A, Fanfani F, Sacco R, De Pasqua A, Mancuso S \& Scambia G 2000 p21WAF1/CIP1 protein expression in primary ovarian cancer. International Journal of Oncology 17 1231-1235.

Ferrandina G, Legge F, Martinelli E, Ranelletti FO, Zannoni GF, Lauriola L, Gessi M, Gallotta V \& Scambia G 2005 Survivin expression in ovarian cancer and its correlation with clinico-pathological, surgical and apoptosis-related parameters. British Journal of Cancer 92 271-277. (doi:10.1038/sj.bjc.6602332)

Gadducci A, Zola P, Landoni F, Maggino T, Sartori E, Bergamino T \& Cristofani R 1995 Serum half-life of CA 125 during early chemotherapy as an independent prognostic variable for patients with advanced epithelial ovarian cancer: results of a multicentric Italian study. Gynecological Oncology 58 42-47. (doi:10.1006/gyno. 1995.1181)

Gadducci A, Ferdeghini M, Cosio S, Fanucchi A, Cristofani R \& Genazzani AR 2001 The clinical relevance of serum CYFRA 21-1 assay in patients with ovarian cancer. International Journal of Gynecological Cancer 11 277-282. (doi:10.1046/j.1525-1438.2001.011004277.x)

Gadducci A, Cosio S, Fanucchi A, Negri S, Cristofani R \& Genazzani AR 2004 The predictive and prognostic value of serum CA 125 half-life during paclitaxel/platinumbased chemotherapy in patients with advanced ovarian carcinoma. Gynecological Oncology 93 131-136. (doi:10.1016/j.ygyno.2003.12.043)

Gautier L, Cope L, Bolstad BM \& Irizarry RA 2004 Affy analysis of Affymetrix GeneChip data at the probe level. Bioinformatics 20 307-315. (doi:10.1093/bioinformatics/ btg405)

Green JA, Berns EM, Coens C, van Luijk I, Thompson-Hehir J, van Diest P, Verheijen RH, van de Vijver M, van Dam P, Kenter GG et al. 2006 Alterations in the p53 pathway and prognosis in advanced ovarian cancer: a multi-factorial analysis of the EORTC Gynaecological Cancer group (study 55865). European Journal of Cancer 42 2539-2548. (doi:10.1016/j.ejca.2006.06.015)

Gyorffy B, Dietel M, Fekete T \& Lage H 2008 A snapshot of microarray-generated gene expression signatures associated with ovarian carcinoma. International Journal of Gynecological Cancer 18 1215-1233. (doi:10.1111/ j.1525-1438.2007.01169.x)

Gyorffy B, Lanczky A, Eklund AC, Denkert C, Budczies J, Li Q \& Szallasi Z 2010 An online survival analysis tool to rapidly assess the effect of 22277 genes on breast cancer prognosis using microarray data of 1809 patients. Breast Cancer Research and Treatment 123 725-731.

Gyorffy B, Molnar B, Lage H, Szallasi Z \& Eklund AC 2009 Evaluation of microarray preprocessing algorithms based on concordance with RT-PCR in clinical samples. PLoS ONE 4 e5645. (doi:10.1371/journal.pone.0005645)

Hefler L, Mayerhofer K, Nardi A, Reinthaller A, Kainz C \& Tempfer C 2000 Serum soluble Fas levels in ovarian cancer. Obstetrics and Gynecology 96 65-69. (doi:10.1016/S0029-7844(00)00840-1)
Hefler LA, Zeillinger R, Grimm C, Sood AK, Cheng WF, Gadducci A, Tempfer CB \& Reinthaller A 2006 Preoperative serum vascular endothelial growth factor as a prognostic parameter in ovarian cancer. Gynecological Oncology 103 512-517. (doi:10.1016/j.ygyno.2006.03.058)

Huhtinen K, Suvitie P, Hiissa J, Junnila J, Huvila J, Kujari H, Setala M, Harkki P, Jalkanen J, Fraser J et al. 2009 Serum HE4 concentration differentiates malignant ovarian tumours from ovarian endometriotic cysts. British Journal of Cancer 100 1315-1319. (doi:10.1038/sj.bjc. 6605011)

Kamat AA, Fletcher M, Gruman LM, Mueller P, Lopez A, Landen CN Jr, Han L, Gershenson DM \& Sood AK 2006 The clinical relevance of stromal matrix metalloproteinase expression in ovarian cancer. Clinical Cancer Research 12 1707-1714. (doi:10.1158/1078-0432.CCR-05-2338)

Katsaros D, Cho W, Singal R, Fracchioli S, Rigault De La Longrais IA, Arisio R, Massobrio M, Smith M, Zheng W, Glass J et al. 2004 Methylation of tumor suppressor gene p16 and prognosis of epithelial ovarian cancer. Gynecological Oncology 94 685-692. (doi:10.1016/j.ygyno. 2004.06.018)

Khouja MH, Baekelandt M, Nesland JM \& Holm R 2007 The clinical importance of Ki-67, p16, p14, and p57 expression in patients with advanced ovarian carcinoma. International Journal of Gynecological Pathology 26 418-425. (doi:10.1097/pgp.0b013e31804216a0)

Kleinberg L, Florenes VA, Silins I, Haug K, Trope CG, Nesland JM \& Davidson B 2007 Nuclear expression of survivin is associated with improved survival in metastatic ovarian carcinoma. Cancer 109 228-238. (doi:10.1002/cncr.22426)

Kommoss S, du Bois A, Ridder R, Trunk MJ, Schmidt D, Pfisterer J \& Kommoss F 2007 Independent prognostic significance of cell cycle regulator proteins p16(INK4a) and $\mathrm{pRb}$ in advanced-stage ovarian carcinoma including optimally debulked patients: a translational research subprotocol of a randomised study of the Arbeitsgemeinschaft Gynaekologische Onkologie Ovarian Cancer Study Group. British Journal of Cancer 96 306-313. (doi:10.1038/sj.bjc.6603531)

Konno R, Takano T, Sato S \& Yajima A 2000 Serum soluble Fas level as a prognostic factor in patients with gynecological malignancies. Clinical Cancer Research 6 3576-3580.

Konstantinidou AE, Korkolopoulou P, Vassilopoulos I, Tsenga A, Thymara I, Agapitos E, Patsouris E \& Davaris P 2003 Reduced retinoblastoma gene protein to Ki-67 ratio is an adverse prognostic indicator for ovarian adenocarcinoma patients. Gynecological Oncology $\mathbf{8 8}$ 369-378. (doi:10.1016/S0090-8258(02)00092-6)

Konstantinopoulos PA, Spentzos D, Karlan BY, Taniguchi T, Fountzilas E, Francoeur N, Levine DA \& Cannistra SA 2010 Gene expression profile of BRCAness that correlates with responsiveness to chemotherapy and with outcome in patients with epithelial ovarian cancer. Journal of Clinical Oncology 28 3555-3561. (doi:10.1200/JCO.2009.27.5719) 
Korkolopoulou P, Vassilopoulos I, Konstantinidou AE, Zorzos H, Patsouris E, Agapitos E \& Davaris P 2002 The combined evaluation of p27Kip1 and Ki-67 expression provides independent information on overall survival of ovarian carcinoma patients. Gynecological Oncology $\mathbf{8 5}$ 404-414. (doi:10.1006/gyno.2002.6627)

Kudoh K, Ichikawa Y, Yoshida S, Hirai M, Kikuchi Y, Nagata I, Miwa M \& Uchida K 2002 Inactivation of p16/CDKN2 and p15/MTS2 is associated with prognosis and response to chemotherapy in ovarian cancer. International Journal of Cancer 99 579-582. (doi:10.1002/ijc.10331)

Lambeck AJ, Crijns AP, Leffers N, Sluiter WJ, ten Hoor KA, Braid M, van der Zee AG, Daemen T, Nijman HW \& Kast WM 2007 Serum cytokine profiling as a diagnostic and prognostic tool in ovarian cancer: a potential role for interleukin 7. Clinical Cancer Research 13 2385-2391. (doi:10.1158/1078-0432.CCR-06-1828)

Lassus H, Leminen A, Vayrynen A, Cheng G, Gustafsson JA, Isola J \& Butzow R 2004 ERBB2 amplification is superior to protein expression status in predicting patient outcome in serous ovarian carcinoma. Gynecological Oncology 92 31-39. (doi:10.1016/j.ygyno.2003.10.010)

Lee YH, Heo JH, Kim TH, Kang H, Kim G, Kim J, Cho SH \& An HJ 2011 Significance of cell cycle regulatory proteins as malignant and prognostic biomarkers in ovarian epithelial tumors. International Journal of Gynecological Pathology 30 205-217. (doi:10.1097/PGP. 0b013e3182063e71)

Levesque MA, Katsaros D, Massobrio M, Genta F, Yu H, Richiardi G, Fracchioli S, Durando A, Arisio R \& Diamandis EP 2000 Evidence for a dose-response effect between p53 (but not p21WAF1/Cip1) protein concentrations, survival, and responsiveness in patients with epithelial ovarian cancer treated with platinum-based chemotherapy. Clinical Cancer Research 6 3260-3270.

Levidou G, Korkolopoulou P, Thymara I, Vassilopoulos I, Saetta AA, Gakiopoulou H, Konstantinidou A, KairiVassilatou E, Pavlakis K \& Patsouris E 2007 Expression and prognostic significance of cyclin D3 in ovarian adenocarcinomas. International Journal of Gynecological Pathology 26 410-417. (doi:10.1097/pgp. Ob013e31804630a7)

Luo LY, Katsaros D, Scorilas A, Fracchioli S, Piccinno R, Rigault de la Longrais IA, Howarth DJ \& Diamandis EP 2001 Prognostic value of human kallikrein 10 expression in epithelial ovarian carcinoma. Clinical Cancer Research $72372-2379$.

Marth C, Fiegl H, Zeimet AG, Muller-Holzner E, Deibl M, Doppler W \& Daxenbichler G 2004 Interferon-gamma expression is an independent prognostic factor in ovarian cancer. American Journal of Obstetrics and Gynecology 191 1598-1605. (doi:10.1016/j.ajog.2004.05.007)

Masciullo V, Scambia G, Marone M, Giannitelli C, Ferrandina G, Bellacosa A, Benedetti Panici P \& Mancuso S 1997 Altered expression of cyclin D1 and
CDK4 genes in ovarian carcinomas. International Journal of Cancer 74 390-395. (doi:10.1002/(SICI)10970215(19970822)74:4<390::AID-IJC5 > 3.0.CO;2-Q)

Masciullo V, Ferrandina G, Pucci B, Fanfani F, Lovergine S, Palazzo J, Zannoni G, Mancuso S, Scambia G \& Giordano A 2000 p27Kip1 expression is associated with clinical outcome in advanced epithelial ovarian cancer: multivariate analysis. Clinical Cancer Research 6 4816-4822.

Materna V, Surowiak P, Markwitz E, Spaczynski M, DragZalesinska M, Zabel M \& Lage H 2007 Expression of factors involved in regulation of DNA mismatch repairand apoptosis pathways in ovarian cancer patients.

Oncology Reports 17 505-516.

Meden H, Marx D, Raab T, Kron M, Schauer A \& Kuhn W 1995 EGF-R and overexpression of the oncogene c-erbB2 in ovarian cancer: immunohistochemical findings and prognostic value. Journal of Obstetrics and Gynaecology 21 167-178.

Milde-Langosch K, Hagen M, Bamberger AM \& Loning T 2003 Expression and prognostic value of the cell-cycle regulatory proteins, Rb, p16MTS1, p21WAF1, p27KIP1, cyclin E, and cyclin D2, in ovarian cancer. International Journal of Gynecological Pathology 22 168-174. (doi:10. 1097/00004347-200304000-00009)

Mok SC, Bonome T, Vathipadiekal V, Bell A, Johnson ME, Wong KK, Park DC, Hao K, Yip DK, Donninger H et al. 2009 A gene signature predictive for outcome in advanced ovarian cancer identifies a survival factor: microfibrilassociated glycoprotein 2. Cancer Cell 16 521-532. (doi:10.1016/j.ccr.2009.10.018)

Moore RG, McMeekin DS, Brown AK, DiSilvestro P, Miller MC, Allard WJ, Gajewski W, Kurman R, Bast RC Jr, Skates SJ et al. 2009 A novel multiple marker bioassay utilizing HE4 and CA125 for the prediction of ovarian cancer in patients with a pelvic mass. Gynecological Oncology 112 40-46. (doi:10.1016/j.ygyno.2008.08.031)

Moore RG, Jabre-Raughley M, Brown AK, Robison KM, Miller MC, Allard WJ, Kurman RJ, Bast RC \& Skates SJ 2010 Comparison of a novel multiple marker assay vs the risk of malignancy index for the prediction of epithelial ovarian cancer in patients with a pelvic mass. American Journal of Obstetrics and Gynecology 203 228.e1-228.e6. (doi:10.1016/j.ajog.2010.03.043)

Newcomb EW, Sosnow M, Demopoulos RI, ZeleniuchJacquotte A, Sorich J \& Speyer JL 1999 Expression of the cell cycle inhibitor p27KIP1 is a new prognostic marker associated with survival in epithelial ovarian tumors. American Journal of Pathology 154 119-125. (doi:10.1016/S0002-9440(10)65258-3)

Nielsen JS, Jakobsen E, Holund B, Bertelsen K \& Jakobsen A 2004 Prognostic significance of p53, Her-2, and EGFR overexpression in borderline and epithelial ovarian cancer. International Journal of Gynecological Cancer 14 1086-1096. (doi:10.1111/j.1048-891X.2004.14606.x)

Plisiecka-Halasa J, Karpinska G, Szymanska T, Ziolkowska I, Madry R, Timorek A, Debniak J, Ulanska M, Jedryka M, Chudecka-Glaz A et al. 2003 P21WAF1, P27KIP1, TP53 
and C-MYC analysis in 204 ovarian carcinomas treated with platinum-based regimens. Annals of Oncology 14 1078-1085. (doi:10.1093/annonc/mdg299)

Psyrri A, Kassar M, Yu Z, Bamias A, Weinberger PM, Markakis S, Kowalski D, Camp RL, Rimm DL \& Dimopoulos MA 2005 Effect of epidermal growth factor receptor expression level on survival in patients with epithelial ovarian cancer. Clinical Cancer Research 11 8637-8643. (doi:10.1158/1078-0432.CCR-05-1436)

Psyrri A, Yu Z, Bamias A, Weinberger PM, Markakis S, Kowalski D, Camp RL, Rimm DL \& Dimopoulos MA 2006 Evaluation of the prognostic value of cellular inhibitor of apoptosis protein in epithelial ovarian cancer using automated quantitative protein analysis. Cancer Epidemiology, Biomarkers \& Prevention 15 1179-1183. (doi:10.1158/1055-9965.EPI-06-0120)

Reimer D, Sadr S, Wiedemair A, Stadlmann S, Concin N, Hofstetter G, Muller-Holzner E, Marth C \& Zeimet AG 2007 Clinical relevance of E2F family members in ovarian cancer - an evaluation in a training set of 77 patients. Clinical Cancer Research 13 144-151. (doi:10.1158/1078-0432.CCR-06-0780)

Reles A, Wen WH, Schmider A, Gee C, Runnebaum IB, Kilian U, Jones LA, El-Naggar A, Minguillon C, Schonborn I et al. 2001 Correlation of p53 mutations with resistance to platinum-based chemotherapy and shortened survival in ovarian cancer. Clinical Cancer Research 7 2984-2997.

Riedinger JM, Wafflart J, Ricolleau G, Eche N, Larbre H, Basuyau JP, Dalifard I, Hacene K \& Pichon MF 2006 CA 125 half-life and CA 125 nadir during induction chemotherapy are independent predictors of epithelial ovarian cancer outcome: results of a French multicentric study. Annals of Oncology 17 1234-1238. (doi:10.1093/ annonc/mdl120)

Riener EK, Arnold N, Kommoss F, Lauinger S \& Pfisterer J 2004 The prognostic and predictive value of immunohistochemically detected HER-2/neu overexpression in 361 patients with ovarian cancer: a multicenter study. Gynecological Oncology 95 89-94. (doi:10.1016/j.ygyno. 2004.06.048)

Rosen DG, Yang G, Deavers MT, Malpica A, Kavanagh JJ, Mills GB \& Liu J 2006 Cyclin E expression is correlated with tumor progression and predicts a poor prognosis in patients with ovarian carcinoma. Cancer 106 1925-1932. (doi:10.1002/cncr.21767)

Ross JS, Yang F, Kallakury BV, Sheehan CE, Ambros RA \& Muraca PJ 1999 HER-2/neu oncogene amplification by fluorescence in situ hybridization in epithelial tumors of the ovary. American Journal of Clinical Pathology 111 311-316.

Rubin SC, Finstad CL, Wong GY, Almadrones L, Plante M \& Lloyd KO 1993 Prognostic significance of HER-2/neu expression in advanced epithelial ovarian cancer: a multivariate analysis. American Journal of Obstetrics and Gynecology 168 162-169.
Rustin GJ, Gennings JN, Nelstrop AE, Covarrubias H, Lambert HE \& Bagshawe KD 1989 Use of CA-125 to predict survival of patients with ovarian carcinoma. North Thames Cooperative Group. Journal of Clinical Oncology 7 1667-1671.

Sawada K, Radjabi AR, Shinomiya N, Kistner E, Kenny H, Becker AR, Turkyilmaz MA, Salgia R, Yamada SD, Vande Woude GF et al. 2007 c-Met overexpression is a prognostic factor in ovarian cancer and an effective target for inhibition of peritoneal dissemination and invasion. Cancer Research 67 1670-1679. (doi:10.1158/00085472.CAN-06-1147)

Scambia G, Testa U, Benedetti Panici P, Foti E, Martucci R, Gadducci A, Perillo A, Facchini V, Peschle C \& Mancuso S 1995 Prognostic significance of interleukin 6 serum levels in patients with ovarian cancer. British Journal of Cancer 71 354-356. (doi:10.1038/bjc.1995.71)

Schmider A, Gee C, Friedmann W, Lukas JJ, Press MF, Lichtenegger W \& Reles A 2000 p21 (WAF1/CIP1) protein expression is associated with prolonged survival but not with p53 expression in epithelial ovarian carcinoma. Gynecological Oncology 77 237-242. (doi:10.1006/gyno.2000.5748)

Schmider-Ross A, Pirsig O, Gottschalk E, Denkert C, Lichtenegger W \& Reles A 2006 Cyclin-dependent kinase inhibitors CIP1 (p21) and KIP1 (p27) in ovarian cancer. Journal of Cancer Research and Clinical Oncology 132 163-170. (doi:10.1007/s00432-005-0057-5)

Schuyer M, van der Burg ME, Henzen-Logmans SC, Fieret JH, Klijn JG, Look MP, Foekens JA, Stoter G \& Berns EM 2001 Reduced expression of BAX is associated with poor prognosis in patients with epithelial ovarian cancer: a multifactorial analysis of TP53, p21, BAX and BCL-2. British Journal of Cancer 85 1359-1367. (doi:10.1054/ bjoc.2001.2101)

Secord AA, Lee PS, Darcy KM, Havrilesky LJ, Grace LA, Marks JR \& Berchuck A 2006 Maspin expression in epithelial ovarian cancer and associations with poor prognosis: a Gynecologic Oncology Group study. Gynecological Oncology 101 390-397. (doi:10.1016/j. ygyno.2006.02.014)

Sevelda P, Schemper M \& Spona J 1989 CA 125 as an independent prognostic factor for survival in patients with epithelial ovarian cancer. American Journal of Obstetrics and Gynecology 161 1213-1216.

Sillanpaa S, Anttila M, Voutilainen K, Ropponen K, Turpeenniemi-Hujanen T, Puistola U, Tammi R, Tammi M, Sironen R, Saarikoski S et al. 2007 Prognostic significance of matrix metalloproteinase-9 (MMP-9) in epithelial ovarian cancer. Gynecological Oncology 104 296-303. (doi:10.1016/j.ygyno.2006.09.004)

Sims AH, Smethurst GJ, Hey Y, Okoniewski MJ, Pepper SD, Howell A, Miller CJ \& Clarke RB 2008 The removal of multiplicative, systematic bias allows integration of breast cancer gene expression datasets - improving metaanalysis and prediction of prognosis. BMC Medical Genomics 1 42. (doi:10.1186/1755-8794-1-42) 
Skirnisdottir I, Sorbe B \& Seidal T 2001 P53, bcl-2, and bax: their relationship and effect on prognosis in early stage epithelial ovarian carcinoma. International Journal of Gynecological Cancer 11 147-158. (doi:10.1046/j.15251438.2001.01003.x)

Skirnisdottir I, Seidal T \& Sorbe B 2004 A new prognostic model comprising p53, EGFR, and tumor grade in early stage epithelial ovarian carcinoma and avoiding the problem of inaccurate surgical staging. International Journal of Gynecological Cancer 14 259-270. (doi:10.1111/j.1048-891X.2004.014209.x)

Skirnisdottir IA, Sorbe B, Lindborg K \& Seidal T 2011 Prognostic impact of p53, p27, and C-MYC on clinicopathological features and outcome in early-stage (FIGO I-II) epithelial ovarian cancer. International Journal of Gynecological Cancer 21 236-244. (doi:10.1097/IGC.0b013e31820986e5)

Smith-Sorensen B, Kaern J, Holm R, Dorum A, Trope C \& Borresen-Dale AL 1998 Therapy effect of either paclitaxel or cyclophosphamide combination treatment in patients with epithelial ovarian cancer and relation to TP53 gene status. British Journal of Cancer 78 375-381. (doi:10.1038/bjc.1998.502)

Suh DS, Yoon MS, Choi KU \& Kim JY 2008 Significance of E2F-1 overexpression in epithelial ovarian cancer. International Journal of Gynecological Cancer 18 492-498. (doi:10.1111/j.1525-1438.2007.01044.x)

Sui L, Dong Y, Ohno M, Sugimoto K, Tai Y, Hando T \& Tokuda M 2001 Implication of malignancy and prognosis of p27(kip1), Cyclin E, and Cdk2 expression in epithelial ovarian tumors. Gynecological Oncology 83 56-63. (doi:10.1006/gyno.2001.6308)

Sui L, Dong Y, Ohno M, Watanabe Y, Sugimoto K \& Tokuda M 2002 Survivin expression and its correlation with cell proliferation and prognosis in epithelial ovarian tumors. International Journal of Oncology 21 315-320.

Tai YT, Lee S, Niloff E, Weisman C, Strobel T \& Cannistra SA 1998 BAX protein expression and clinical outcome in epithelial ovarian cancer. Journal of Clinical Oncology 16 2583-2590.

Tam KF, Liu VW, Liu SS, Tsang PC, Cheung AN, Yip AM \& Ngan HY 2007 Methylation profile in benign, borderline and malignant ovarian tumors. Journal of Cancer Research and Clinical Oncology 133 331-341. (doi:10.1007/s00432-006-0178-5)

Tan PK, Downey TJ, Spitznagel EL Jr, Xu P, Fu D, Dimitrov DS, Lempicki RA, Raaka BM \& Cam MC 2003 Evaluation of gene expression measurements from commercial microarray platforms. Nucleic Acids Research 31 5676-5684. (doi:10.1093/nar/gkg763)
TCGA 2011 Integrated genomic analyses of ovarian carcinoma. Nature 474 609-615. (doi:10.1038/ nature10166)

Tempfer C, Hefler L, Heinzl H, Loesch A, Gitsch G, Rumpold H \& Kainz C 1998 CYFRA21-1 serum levels in women with adnexal masses and inflammatory diseases. British Journal of Cancer 78 1108-1112. (doi:10.1038/ bjc.1998.636)

Thrall M, Gallion HH, Kryscio R, Kapali M, Armstrong DK \& DeLoia JA 2006 BRCA1 expression in a large series of sporadic ovarian carcinomas: a Gynecologic Oncology Group study. International Journal of Gynecological Cancer 16 (Suppl 1) 166-171. (doi:10.1111/j.1525-1438. 2006.00504.x)

Torng PL, Mao TL, Chan WY, Huang SC \& Lin CT 2004 Prognostic significance of stromal metalloproteinase-2 in ovarian adenocarcinoma and its relation to carcinoma progression. Gynecological Oncology 92 559-567. (doi:10.1016/j.ygyno.2003.11.011)

Tothill RW, Tinker AV, George J, Brown R, Fox SB, Lade S, Johnson DS, Trivett MK, Etemadmoghadam D, Locandro B et al. 2008 Novel molecular subtypes of serous and endometrioid ovarian cancer linked to clinical outcome. Clinical Cancer Research 14 5198-5208. (doi:10.1158/ 1078-0432.CCR-08-0196)

Wang Y, Helland A, Holm R, Skomedal H, Abeler VM, Danielsen HE, Trope CG, Borresen-Dale AL \& Kristensen GB 2004 TP53 mutations in early-stage ovarian carcinoma, relation to long-term survival. British Journal of Cancer 90 678-685. (doi:10.1038/sj.bjc. 6601537)

Widschwendter A, Muller HM, Hubalek MM, Wiedemair A, Fiegl H, Goebel G, Mueller-Holzner E, Marth C \& Widschwendter M 2004 Methylation status and expression of human telomerase reverse transcriptase in ovarian and cervical cancer. Gynecological Oncology 93 407-416. (doi:10.1016/j.ygyno.2004.01.036)

Wisman GB, Hollema H, Helder MN, Knol AJ, Van der Meer GT, Krans M, De Jong S, De Vries EG \& Van der Zee AG 2003 Telomerase in relation to expression of p53, c-Myc and estrogen receptor in ovarian tumours. International Journal of Oncology 23 1451-1459.

Received in final form 17 January 2012 Accepted 24 January 2012 Made available online as an Accepted Preprint 25 January 2012 